\title{
PROVING AL-MAQRIZI'S CONCEPT OF THE DETERMINANTS OF INFLATION: CROSS BORDER ANALYSIS
}

\author{
Nashr Akbar ${ }^{1}$ and Abdul Wahid al Faizin ${ }^{2}$ \\ ${ }^{1}$ Tazkia Islamic University College, Indonesia, n.akbar@tazkia.ac.id \\ ${ }^{2}$ Airlangga University, Indonesia, alfaiz165@gmail.com
}

\begin{abstract}
This research discusses the determinants of inflation according to Al-Maqrizi, one of Ibnu Khaldun's disciples. He argued that inflation is caused by natural and human error factors; the latter include government corruption and the excess supply of non-metal money. This study conducts a critical review of the work of al-Maqrizi, ighatsatul ummah bi kasyfil ghummah, supported by a panel data regression of cross-country data related to rates of inflation, rates of corruption and the number of natural disasters. The empirical data show that the rate of inflation is positively related to human error factors: corruption, tax and money supply. The results indicate the relevance of al-Maqirizi's postulates to the modern day economy. However, natural disasters are not proven to be a significant factor for inflation at the country level. This paper contributes to the importance of the study of classical Muslim scholars' thinking in order to understand current economic problems and ways of solving them.
\end{abstract}

Keywords: Corruption, Inflation, Al-Maqrizi, Natural Disaster, Money Supply. JEL Classification: B11; E31; E43; G10.

Article history:

Received : September 26, 2019

Revised : December 9, 2019

Accepted : December 23, 2019

Available online : December 27, 2019

https://doi.org/10.21098/jimf.v5i4.1142 


\section{INTRODUCTION}

\subsection{Background}

One of the main tasks of government in the macroeconomic field is to maintain price stability (Case et al., 2012). Therefore, the level of inflation/deflation is a macroeconomic indicator to which attention should be paid. Inflation has various negative impacts on the economy; in general, economists agree that high inflation can reduce people's welfare and economic growth (Phiri, 2018; Aisen \& Veiga, 2006; Sarel, 1996) and also reduce the level of corporate profits (Doepke \& Schneider, 2006). Furthermore, Ascarya (2017) employed the inflation variable as an indicator of crisis.

In a global context, uncontrolled inflation could become a serious problem that triggers a crisis. Financial crises have occurred one after another since the occurrence of hyperinflation in Germany in 1922-1923, which was then followed by the Great Depression of 1929-1930. Subsequently, there was also a financial crisis in Austria (the banking crisis of 1931); France (hyperinflation in the period 1944-1966); Hungary (hyper and monetary inflation in 1944-1946), Germany (inflation which declined in 1945-1946), and Nigeria (banking crisis in 1945-1955). However, after the Bretton Woods Agreement crises subsided between 1950 and 1972, although after the collapse of this agreement, they reappeared even more frequently. There was a financial crisis in the UK (banking crisis of 1973-1974); in industrialized countries (major recession in 1978-1980); in developing countries (debt crisis of 1980-1982); a crisis in the US and the UK (stock market collapse in 1987); in Mexico (financial crisis in 1994); and in Asian countries including Indonesia, and in Russia, Brazil and Argentina (financial crisis and hyperinflation in 1997-1999). The latest crisis triggered by subprime mortgages that occurred in the US spread throughout the world (Ascarya, 2011). Laeven and Valencia (2012) note that there were 268 crises from 1970 to 2011, which consisted of banking, debt and currency-related ones.

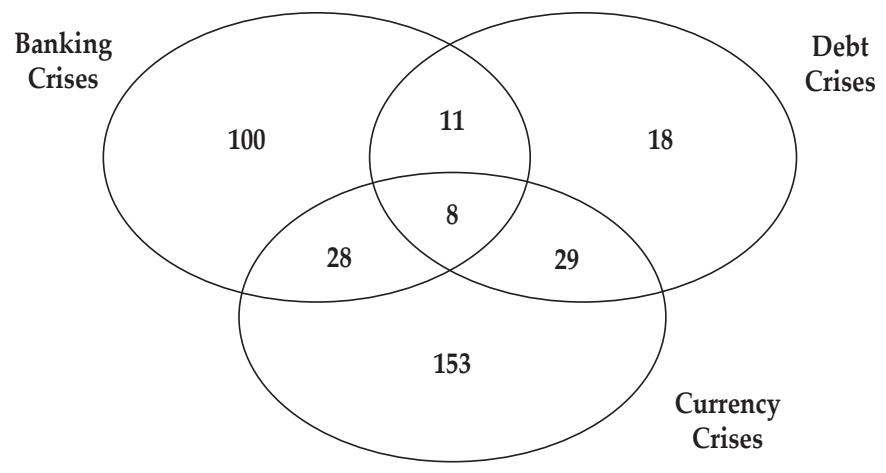

Source: Adapted from Laeven \& Valencia (2012).

Figure 1.

Financial Crises in 1970-2011

Many theories developed by conventional economists are related to the causes of inflation and how to solve them. From the conventional economic perspective, the causes of inflation include demand-pull inflation, cost-push inflation and 
expectations. However, the successive crises, as detailed above, are evidence of the failure of the current economy to learn lessons on how to cope with, and control, inflation well (Ascarya, 2017). Therefore, there is an urgent need to find other perspectives or theories that may create price stability.

In the history of Islam, inflation has also occurred, even in the time of Rasulullah. It is narrated by al-Thabrani $(1995: 1,187)$ that in the time of Rasulullah, there was a terrible drought in Medina that caused a plummeting of agricultural products and the death of many livestock. The drop in agrarian products then caused an increase in prices (inflation). A similar case also occurred in the time of al-Khulafa 'al-Rashidun, especially in the time of the Khalifa Umar bin Khattab, which was known as "'Aam ar-Ramaadah" (a grey year, or year of suffering) (Al-Harisi, 2003: 313).

Inflation not only occurred in the time of Rasulullah and al-Khulafa 'alRashidun, but also in the time of the following Khalifas. The series of inflation was recorded and then examined by a classical Muslim economist named Abu Al-Abbas Ahmad bin Ali Al-Maqrizi in his book Ighatsah Al-Ummah bi Kasyfi AlGhummah. In this, Al-Maqrizi reveals several series of inflation that had occurred in Egypt, from BC to the period of the Khalifas in his time.

In his research on the history of inflation that had occurred, Al-Maqrizi (2007: 115-117) concluded that globally there were two types of causes of inflation. First, natural inflation, which is due to natural disasters, and second, inflation due to human error, including corruption, high taxes and excessive printing of fulus (cooper currency).

In fact, some studies have partially proven the positive relationship between inflation and some of the factors mentioned by Al-Maqrizi. For instance, Parker (2016) found a positive relationship between natural disasters and inflation in developing countries, but not in developed ones. Al-Marhubi (2000) and Samimi et al. (2012) proved the positive relationship between corruption and inflation.

To date, few researchers have examined the overall causes of inflation mentioned by Al-Maqrizi. Ascarya (2011) referred to al-Maqrizi in his classification of inflation into natural and human error induced, with some modifications. However, the object of study was limited to Indonesia. To the best of the author's knowledge, no empirical research examines the validity of al-Maqrizi's thoughts with panel data or across countries.

\subsection{Objective}

Finding the real root of crises is the key to finding better solutions. This paper analyses the factors that have influenced inflation in various countries from the perspective of al-Maqrizi. The author would like to ascertain whether the inflation factors mentioned by al-Maqrizi also affect the current level of inflation in the observed countries. 


\section{LITERATURE REVIEW}

\subsection{Background Theory}

2.1.1. Inflation from a Conventional Perspective

There are different theories based on conventional perspectives:

\section{1) Quantity Theory of Money}

This theory argues that money supply is the main root of inflation. The related equation was developed as follows:

$$
\begin{array}{llll}
\text { M } & \text { V } & \text { P } & \text { Y } \\
\text { Money X Velocity } & = & \text { Price } & \text { X Output }
\end{array}
$$

As velocity is assumed to be constant, any change in money supply affects the nominal value of PY. Moreover, as the percentage change in output depends on the growth of factors of production and on technological progress, hence the change in price (inflation) primarily depends on the change in money supply. To conclude, central banks, which control money supply, have the control over the rate of inflation (Mankiw, 2016).

\section{2) Demand-Pull Inflation}

Any factor that increases aggregate demand is called demand-pull inflation. Some of the factors are a reduction in the interest rate, an increase in money supply, an increase in government expenditure, a tax deduction, an increase in exports, or a rise in investment due to an increase in expected future profits (Parkin, 2012).

\section{3) Cost-Push Inflation}

An increase in costs that shifts aggregate supply to the left is called cost-push inflation. There are two main factors that increase costs: a) a rise in the money wage rate, and 2) an increase in the money price of raw materials, such as oil (Parkin, 2012).

\subsubsection{Inflation from the perspective of Al-Maqrizi}

Abu Al-Abbas Ahmad bin Ali Al-Maqrizi is an Islamic economic figure who shows great concern about inflation. In his groundbreaking book Ighatsah Al-Mummah bi Kasyfi Al-Ghummah, he conducted a study of the history of inflation in Egypt. However, to complete understanding of Al-Maqrizi, this paper will give a brief overview of inflation in the Islamic period.

In the early period of Islam, financial crises were not known. Any crises that did exist were more crises in the real sector, which were mostly caused by natural disasters such as drought and famine. However, ultimately such crises often also affect price stability, which is reflected in rising prices of goods (inflation). Examples of inflation that occurred in the early Islamic period caused by crises in the real sector due to natural disasters were as follows: 
1. Inflation in the time of Rasulullah

Al-Thabrani (1995: 1,187), in his book Al-Mu'jam Al-Ausath, narrates from Anas bin Malik that in the time of Rasulullah there was a drought in Medina. This caused a water crisis which ultimately led to the plummeting supply of agricultural products and the death of many livestock. This drop in agrarian products then caused an increase in prices (inflation).

The lack of water and agricultural products was also accompanied by the rise of the inflation rate and caused concern among friends, so they asked Rasulullah, as the Messenger of Allah, to pray to Allah to make it rain. Rasulullah then prayed, and Allah answered his prayers by sending the country rain for seven days. Because the rain continued for seven days, the friends were afraid of a big flood and asked Rasulullah to pray to make the rain stop. Rasulullah then prayed:

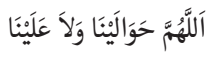

"O Allah, let the rain fall around us, not above us."

2. Inflation in the time of Umar bin Khattab

During the time of Umar bin Khattab, there was inflation which was also caused by a long dry season known as عام الرمادة (a grey year or year of suffering). This resulted in inflation occurring in 18 Hijriyyah and lasted for almost five years, as recounted in the history by Al-Qurthubi (Al-Harisi, 2003: 313).

In addition, the series of inflation events that has occurred in Egypt in several periods of Islamic Khalifa is explained by Al-Maqrizi (2007) as follows:

1. The period of leadership of Abdullah bin Abdul Malik bin Marwan.

In the period of Abdullah bin Abdul Malik bin Marwan, who was the amir (governor) of Egypt during the Umayyad Khalifa, inflation occurred for the first time in the Islamic period in Egypt, in the year $87 \mathrm{H}$. Previously, inflation had occurred when the Prophet Moses was sent to Fir'aun, as mentioned in the surah Al-A'raf: 130 (Al-Maqrizi, 2007: 85).

2. The period of the Ikhsyidiyyah dynasty.

In the year $341 \mathrm{H}$, in the reign of Unujur bin Ikhsyid, inflation occurred due to the declining state output caused by rat attacks that damaged the agricultural products. The inflation continued to increase and peaked in $343 \mathrm{H}$. This triggered public outrage, so action was taken to destroy public facilities. In the next regime, which was under the leadership of Ali bin Ikhsyid, the inflation rate had reached 300\% (hyperinflation). This worsened the situation, until finally people held a demonstration, which resulted in the death of a man and a woman (Al-Maqrizi, 2007: 86-87).

3. The period of the Al-Hakim bi Amrillah of Fatimiyyah dynasty.

The inflation that occurred in the period of Al-Hakim bi Amrillah was different from that which had occurred in previous periods, both in the early Islamic period and the Ikhsyidiyyah dynasty period. While in these previous periods inflation had been mostly caused by natural factors such as drought and outbreaks of disease, during Al-Hakim's time, besides the natural elements, inflation was also exacerbated by the practice of rent-seeking on financial markets (in this case the instruments used were the dirham and dinar). The practice was also exacerbated by the behaviour of cutting or reducing the 
official dirham currency that was being circulated (debasement). As a result, the dirham and dinar became unstable. For example, the initial dinar exchange rate was 1 dinar $=26$ dirhams, but in $97 \mathrm{H}$ this rose to 1 dinar $=34$ dirhams.

The monetary authority, Baitul Mal, attempted to control market operations by pouring new dirhams into the market to overcome the problem. It also prohibited the use of dirhams that had changed size and pulled them out of circulation to be reprinted. They withdrew the old dirhams that had been altered and circulated in the community and allowed each new dirham to be exchanged for four dirhams that already changed in size (Al-Maqrizi, 2007: 89-91).

When the period of Al-Hakim bi Amrillah ended, crises still often occurred in the periods of government that followed, including ones in the periods of AlMuntashir, Al-Amir bi Hukmillah, Al-Hafidz li Dinillah, Al-Faiz bi Nashrillah, Al-Adil Al-Ayyubi, Al-Adil Kotboga and Al-Ashraf Sya'ban. As in the Al-Hakim period, the financial crises that ensued were also heavily influenced by the monetary system and poor state governance (Al-Maqrizi, 2007: 92-114).

\subsubsection{The Determinants of Inflation}

According to Al-Maqrizi, inflation that has existed globally since early human existence has been caused by disasters, such as the receding Nile river water in Egypt the prolonged drought in Sham, Iraq, Hijaz and other areas; and diseases affecting agricultural and plantation products in the form of wind, pest attacks and similar problems. These inflation factors also happened in the times of Rasulullah and Umar bin Khattab, as explained earlier. According to Al-Maqrizi, inflation factors such as these are natural because they are sunnatullah. Price increases due to inflation factors will gradually decline along with the disappearance of the effects of disaster, the source of the cause (Al-Maqrizi, 2007: 115).

Interestingly, according to Al-Maqrizi, inflation in his time was mostly caused by factors other than natural factors. In other words, inflation in the Al-Maqrizi era was mostly caused by human error factors, of which there are three main types which can result in inflation according to Al-Maqrizi, namely:

1. The spread of bribery practice in government.

According to Al-Maqrizi, this factor was the main one in the occurrence of inflation which subsequently led to various financial crises in the country. The practice of bribery in Al-Maqrizi's era existed in almost all sectors, ranging from ministries, the judiciary, managers of irrigation, hisbah councils (market supervisors such as KPPU), and even in the realm of religious departments. It was concluded that the country had many ignorant and depraved people who obtained their strategic positions and big projects by giving large bribes to those in power.

The parties who made these large bribes often used debt for their initial bribe money fund. This resulted in the amount of debt they bore not being proportional to the results of the position or project they were wanted to influence. This made them cover their eyes, at the expense of small communities. As a result, there were many practices of collecting large taxes or illegal fees from the public. Moreover, they were also encouraged to corrupt people's property in their territory. 
In addition, the authorities hoarded large amounts of staple food that was needed by the community, with the aim of obtaining as much profit as possible. As a result, the economy collapsed because there several other bad situations followed, such as prices which increased uncontrollably, and the stock of food supply running low due to the hoarding. This condition then makes community life miserable, with widespread hunger (Al-Maqrizi, 2007: 92-114). According to the word of Allah:

"And if We want to destroy a country, then We command those who live in luxury in that land (to obey God) but they commit iniquity in that country, then it is appropriate to apply to those words (Our provisions), then We destroy that country to its fullest" (QS. Al-Isra': 16)

According to Ibnu Jarir and Ibnu Abbas, the above verse explains that one of the signs of a country that wants to be devastated by God is when the leaders of the country are depraved people who like to live in luxury for their own pleasure (Ibnu Katsir, 1999: 5, 62).

2. High taxes and agricultural land rent.

Besides making bribes to gain a strategic position, people who bribe the government also aim to obtain agricultural land rations. Then it bring out a system of feudalism, with many landlords controlling much agricultural land. The landlords then rent out the agricultural land that they control to farmers at high rents, which could even reach 10 times the previous price.

This conditions are worsened by the high price of plant seeds and the cost of workers (farmers). As a result, the cost of agricultural production increases significantly, and agricultural products become very expensive. Moreover, there is the existence of tributes that must be submitted by the farmers to the authorities. Some of these conditions then made many people begin to leave the agricultural sector. As a result, the scarcity of food is unavoidable (AlMaqrizi, 2007: 119-120).

3. Uncontrolled circulation of fulus currency.

This last factor has received the most attention from Al-Maqrizi. He mentioned that all nations both before the emergence of Islam, such as Persia, Rome, Greece and Bani Israil, up to the formation of the Islamic Khilafah, such as the Umayyad dynasty, Abbasids dynasty, Umayyad II in Andalusia, Bani Saljuq in Turkey and the Mughol dynasty, always used gold and silver as the currency for transactions In fact, according to Al-Maqrizi, no single hadith mentions the use of currencies other than gold and silver.

According to Al-Maqrizi, inflation was caused by uncontrolled printing of fulus currency. This was especially exacerbated by the action of rent-seeking from the printing of this currency. This causes money supply to rise, but on the other hand the output of goods decreases. As a result, there was high inflation (Al-Maqrizi, 2007: 120).

\subsection{Previous Studies}

A number of studies have been conducted to analyse the causes of inflation. The increase in money supply has also been found to be a major contributing factor. The creation of money through a fractional reserve banking (FRB) system has 
resulted in inflation, which becomes a hidden tax for everyone. A further impact is the transfer of ownership to the creators of money (Meera \& Larbani, 2009). The expansion of money through credit creation has an impact on inflation (Ishaq \& Mahjabeen, 2015), while a full reserve banking system is considered to stabilise the price level, even to the point of zero inflation (Lainà, 2019; Kumhof \& Benes, 2012).

Ascarya (2013) examined the causes of crisis in Indonesia, with the variable used to explain itan being the price level (inflation). His results show that interest, regulated prices, food fluctuations and fiat money are the causes of inflationary crisis. In a more comprehensive study, Ascarya (2017) found that an unstable monetary system (interest and fiat money), poor governance (administered prices), an unsustainable fiscal system (volatile food) and the misbehaviour of economic actors (expectation) are the real causes of such a crisis.

A number of studies also explain that corruption influences inflation. AlMarhubi (2000) conducted a study of 41 countries over the period 1980 to 1995. The results show that corruption effects inflation. More recent research has been carried out by Samimi et al. (2012), who studied 25 developing countries and concluded that the higher the level of corruption, the higher the inflation rate.

The effect of natural disasters on inflation was discussed by Parker (2016). The results of his research show that natural disasters do not have an impact on inflation in developed countries, but have a significant impact in developing ones. When considered in detail according to the type of disaster, storms and floods have a short-term impact on inflation. In addition, Zhang et al. (2014) found an impact of natural disasters or domestic agricultural supply shock on inflation in the short to medium run.

Based previous studies, no research includes the inflation factors mentioned by al-Maqrizi in a research model. Moreover, no empirical research on the effect of tax on inflation has been found. Therefore, it is necessary to combine several factors considered by al-Maqrizi into a single model.

\section{METHODOLOGY}

\subsection{Data}

Natural disaster data were obtained through the official website https://www. emdat.be/classification\#Extraterrestrial. Corruption perception index data were obtained from the website www.transparency.org. Money supply data, the ratio of tax revenue to GDP and inflation data were obtained through the World Bank website, https://data.worldbank.org.

The data examined in this study were panel data based on 5 years' observation (2012-2016), with 31 countries observed. Therefore, 155 datasets were examined.

\subsection{Model Development}

The research uses a quantitative approach with the panel data regression method. Based on al-Maqrizi (2017), there are two main inflationary factors, namely natural disasters and human error. The latter comprises corruption, tax and the excess supply of money. 
When natural disasters occur, agricultural and plantation products will experience a decline or even a drying up of food production. As a result, there is a shock to aggregate supply (AS), which impacts on the scarcity of food. On the other hand, natural disasters also increase production costs. When the flow of springs or rivers decreases, farmers will incur additional charges for irrigation from distant springs. Therefore, producers will increase the prices of their products.

Hence, the inflation factor in the form of natural inflation proposed by AlMaqrizi corresponds to the pressure push (cost-push inflation) factor that exists in the modern economy. Therefore, when natural disasters occur, they will potentially cause inflation.

A study by Miles (2016) found a positive correlation between inflation and natural disasters in developing countries. Moreover, Barro (2009) discussed the negative effect of disasters on the welfare of society. Disasters also affect poor people trapped in poverty (Michael et al., 2007; Rentschler, 2013). Heinen et al. (2019) explained further that disasters negatively affect monthly welfare due to price increases.

Hypothesis 1: natural disasters have a positive relationship with the inflation rate.

Furthermore, the inflation factor in the form of corruption and corrupt administration proposed by Al-Maqrizi is also in accordance with the pressure push (cost-push inflation) factor that exists in the modern economy. Therefore, when the level of corruption rises, it will potentially cause inflation. Al-Marhubi, (2000) and Samimi et al. (2012) have also proved this correlation.

Hypothesis 2: corruption and poor administration have a positive relationship with the inflation rate.

With regard to tax and land rental, both are costs imposed on the factors of production. Land during Al-Maqrizi's era was the main production factor and resulted in a significant tax. As with corruption and poor administration, the effect of excessive taxation is efficiency or deadweight loss. The consequence is an increase in production costs, which then has implications for the rising prices of goods, which then trigger inflation.

Based on the explanation above, the inflation factor in the form of high tax proposed by Al-Maqrizi also corresponds to the cost-push inflation factor that exists in the modern economy. Therefore, when the tax level rises, it will potentially cause inflation. Today, the amount of tax paid by people can be measured through the tax revenue to GDP ratio.

Hypothesis 3: tax has a positive relationship with the inflation rate.

Likewise, land tax is a cost that is imposed by the government on factors of production in the form of land. Likewise, the price of seeds and farming costs are costs charged to the factors of production in the form of capital and labour. Therefore, the interest set by the government could be equated with the price of seeds and farmers' costs. The interest is the cost charged to the factor of production in the form of capital. On the other hand, Ascarya $(2013,2017)$ viewed that interest is a variable that contributes to the excess supply of money, which creates an unstable monetary policy.

Hypothesis 4: interest rates have a positive relationship with the inflation rate.

Finally, what was argued by Al-Maqrizi in relation to the printing of excess money (fulus) was in accordance with the inflation factors proposed by monetarists. 
According to monetarists, the most significant factor influencing inflation is money supply; inflation occurs when money supply is excessive. Mankiw (2016) explained that when governments print more money to finance their expenditure, this will cause inflation. Printing money to increase revenue (seigniorage) is like imposing tax on the holders of money, as the value of old money is lower (Mankiw, 2016).

Hypothesis 5: money supply has a positive relationship with the inflation rate.

The panel data regression equation model used in this study is as follows:

$$
Y_{i t}=\alpha_{i}+\beta_{1} X 1_{i t}+\beta_{2} X 2_{i t}+\beta_{3} X 3_{i t}+\beta_{4} X 4_{i t}+\beta_{5} X 5_{i t}+\varepsilon_{i t}
$$

where

$Y_{\text {it }}=$ inflation

$\mathrm{X} 1$ = natural disaster

$\mathrm{X} 2$ = corruption

$\mathrm{X} 3$ = interest rate

$\mathrm{X} 4$ = money supply

$\mathrm{X} 5=\operatorname{tax}$

$\varepsilon_{i t}=$ error coefficient

The dependent variable is inflation as measured by the Consumer Price index, while the independent variable data are natural disasters, interest rates, the corruption perception index, money supply and the tax to GDP ratio. Natural disasters include earthquakes, volcanic activity, extreme weather, storms, floods, landslides, epidemics and celestial impacts, amongst others (https://www.emdat. be/classification\#Extraterrestrial).

The level of corruption of a country is measured using the corruption perception index, which is a composite index that measures the perceptions of business actors and experts in corruption in the public sector, including corruption committed by public servants, state administrators and politicians (Indeks Persepsi Korupsi 2016, 2017).

According to Bank Indonesia, money supply can be defined by its narrow meaning (M1) and broad meaning (M2). M1 includes money held by the public and demand deposits (denominated in rupiahs), while M2 covers M1, quasi money (includes savings, term deposits in rupiah and foreign currencies, and current accounts in foreign currencies), and securities issued by the monetary system which are owned by the domestic private sector and have a remaining term of up to one year. The data used in this study are based on money in its broad sense (broad money).

The interest rate in this paper is the reference rate determined by the central bank of each country. It is based on data published by the IMF and World Bank.

Tax is a mandatory contribution to the state made by individuals or entities based on the law, by not getting a direct reward and used for the needs of the state for the prosperity of the people. To establish the level of taxes charged to the public, the tax indicator used in this study is the ratio of tax revenue to GDP. 


\subsection{Method}

\subsubsection{Model Selection Test}

In this study the panel data regression method was used to solve the problem, because the data are secondary and have the nature of time series, also called annual data, and they consist of variables (cross section) or so-called panel data. For these reasons, the panel data regression method was employed.

\subsubsection{Panel Data Regression Model}

The data observations of the panel data regression model are based on panel data. The use of these provides many statistical and economic advantages. Baltagi (2005) explains that some benefits of using panel data include: a) being able to control the heterogeneity of individuals; b) providing more information and more variety, reducing colinearity between variables, and increasing degrees of freedom more efficiently; c) being better for the study of dynamic adjustments; d) being able to identify and measure effects which cannot be obtained from pure cross section data or pure time series data; and e) providing the possibility to test and build more complex behavioural models.

Based on the time period, panel data regression will search for which data are better from the three approaches used, namely:

1. Pooled Least Squares (Common Effect Model). Based on the common effect approach, intercepts (constants) and slopes (variable coefficients) in the research model are fixed or do not change over time, and are also fixed on each variable studied (cross section). The difference in this model is explained by the interference variable. In this approach, the ordinary least squares (OLS) method can be used.

2. Least Square Dummy Variable (Fixed Effect Model). The assumption in this model is that there are intercept differences between objects, but that the intercepts between times are the same. Based on the fixed effect approach, the intercept (constant) is assumed to be different in each object under study, while the slope (slope/variable coefficient) remains the same. Therefore, a dummy variable is added to explain the difference in the intercept, so the model is often called the least square dummy variable (LSDV) model. Similar to common effects, the fixed effects model is obtained through Ordinary Least Squares (OLS).

3. Random Effects Model. This method assumes that intercept differences between objects and time intervals are use for the errors in the ordinary least squares (OLS) model, meaning the model will be more efficient by avoiding the use of degrees of freedom. Based on the random effects approach, it is assumed that the intercept (constant) is different for each object studied. However, the slope (slope of each variable) is the same. The difference in concept is obtained not because of the dummy variable, but rather is assumed to occur due to the interference variable of each object studied.

\section{Model Selection Test}

Two kinds of test can be conducted to produce an accurate model; a) the Chow test, and b) the Hausman test. 
a) Chow Test

The Chow test, or F-test, is a test to choose whether the model used is pooled least squares or fixed effects. Sometimes there is an assumption that each cross section unit displays the same behaviour, which tends to be unrealistic considering that it is possible that each cross section unit in fact has different behaviour. The Chow test is used to choose between ordinary least squares (OLS) common effects or fixed effects methods.

The hypothesis used in testing this common and fixed effects model is:

$\mathrm{H}_{0}=$ common effects model

$\mathrm{H}_{1}=$ fixed effects model

$\mathrm{H}_{0}$ is rejected if $\rho_{\text {value }}>$ level of significance $5 \%$. Meanwhile, if $\rho_{\text {value }}<$ level of significance, then $\mathrm{H}_{0}$ is rejected and panel data regression using the random effects method continues to be used.

b) Hausman Test

The Hausman test is a statistical test used as a basis for considering whether to use the fixed effects or the random effects model. The basic idea of the test is to compare the two estimators, FEM and REM. It forms a null hypothesis test in which $\mathrm{X}_{\mathrm{it}}$ and $\alpha_{1}$ do not correlate and the alternative hypothesis for the opposite condition.

The hypothesis used in testing this fixed effects and random effects model is: $\mathrm{H}_{0}=$ random effects model

$\mathrm{H}_{1}=$ fixed effects model

$\mathrm{H}_{0}$ is failed to reject if $\rho_{\text {value }}>$ level of significance $5 \%$, so the best model used is the random effect model. Meanwhile, if $\rho_{\text {value }}<$ level of significance, so reject $\mathrm{H}_{0}$ and the best model is the fixed effects model.

c) Lagrange Multiplier (LM) Test

The LM test is used as a statistical consideration when choosing between the random effects model (REM) and the pooled least squares (PLS) model. The hypothesis for this test is as follows:

$\mathrm{H}_{0}=$ pooled least squares model

$\mathrm{H}_{1}=$ random effects model

\section{RESULTS AND ANALYSIS}

\subsection{Results}

Three panel data approaches were employed, namely PLS, FEM and REM. The estimates show a variety of results, so it is necessary to choose from one of these using the Chow and Hausman tests. Both tests showed rejection of the null hypothesis, therefore the FEM model was the one used (see Table 1). 
Table 1.

Panel Data Results

\begin{tabular}{|c|c|c|c|c|c|c|c|c|}
\hline 冫 & PLS & & FEM & & REM & & & \\
\hline \multirow[t]{2}{*}{ Constant } & 114.6964 & * & 8.750148 & & 106.2821 & * & & \\
\hline & $(0.0000)$ & & $(0.7504)$ & & $(0.0000)$ & & & \\
\hline \multirow[t]{2}{*}{ Corruption } & -0.129436 & & 1.025418 & * & -0.07039 & & & \\
\hline & $(0.0630)$ & & $(0.0252)$ & & (0.5016) & & & \\
\hline \multirow[t]{2}{*}{ Interest } & 0.944120 & & 1.940674 & * & 1.159872 & * & & \\
\hline & $(0.0000)$ & & $(0.0000)$ & & $(0.0000)$ & & & \\
\hline \multirow[t]{2}{*}{ Money Supply } & $8.31 \mathrm{E}-16$ & & $1.66 \mathrm{E}-14$ & * & 2.26E-15 & & & \\
\hline & (0.5395) & & $(0.0297)$ & & $(0.2734)$ & & & \\
\hline \multirow[t]{2}{*}{ Tax } & 0.170963 & & 2.397767 & * & 0.406329 & & & \\
\hline & (0.4732) & & $(0.0097)$ & & $0.2506)$ & & & \\
\hline \multirow[t]{2}{*}{ N Disaster } & -0.227195 & & -0.18583 & & -0.26202 & & & \\
\hline & $(0.1845)$ & & $(0.3562)$ & & $(0.1328)$ & & & \\
\hline \multirow[t]{2}{*}{ Chow Test } & & & & & & & 4.196060 & * \\
\hline & & & & & & & $(0.0000)$ & \\
\hline \multirow[t]{2}{*}{ Hausman Test } & & & & & & & 20.775779 & * \\
\hline & & & & & & & $(0.0009)$ & \\
\hline
\end{tabular}

Note: * Significant at level of significance of $5 \% ;(\ldots)$ represent P-value

In the FEM approach, it is known that the R-Squared is 0.665673 . This shows that the model used in the study was able to explain the cause of inflation by $66.6 \%$. In other words, $33.3 \%$ of the causes of inflation are explained outside the model. However, this figure is good enough to represent the causes. In addition, the Prob (F-statistic) value of 0.0000 indicates that in general the model with the FEM approach has been rated as good.

Based on the T-statistics of each independent variable in the FEM model, it is shown that all the variables, human error, corruption, interest, money supply and tax, independently and significantly influence the inflation rate. This is also shown from the p-value which is smaller than $5 \%$, meaning that $\mathrm{H}_{0}$ is rejected. The independent variables therefore have a significant influence on the dependent variable, inflation.

\subsection{Analysis}

Based on the estimation, it can be seen that statistically the corruption variable shows a positive influence. This is in line with what was discovered by Al-Marhubi (2000) and Samimi et al. (2012), that the higher the level of corruption, the higher the inflation rate. As a result, as stated by al-Maqrizi, the practice of bribery or corruption could increase costs for producers, thus encouraging them to raise prices to achieve the desired level of profit. The coefficient value for the corruption variable of 1.02542 shows that if there is an increase in the corruption perception index of one unit, while the other variables are fixed, this it will increase the CPI value by 1.32032. Vice versa, if corruption decreases by one unit, while other variables remain unchanged, this will reduce the CPI value by 1.32032 . 
Furthermore, the interest variable statistically shows a positive effect. These results are in line with the findings of Ascarya (2017), that interest rates (unstable monetary system) have an affect on financial crises. During al-Maqrizi's time, interest rates as government policy certainly did not exist. However, the determination of interest rates could be categorised as taxation of the public, which means that interest is a burden on producers. The coefficient value for the interest rate variable of 1.940674 shows that if there is an increase in the interest rate of 1 percent, or 100 basis points, while other variables are fixed, this it will increase the CPI value of 1.940674 . Vice versa, if the interest rate decreases by 1 percent, while other variables remain the same, this will decrease the CPI value by 1.940674 .

It can also be seen that the money supply variable shows a positive effect. This result is in accordance with Ascarya (2017), and proves the significant influence of money supply on the inflation rate. The increase in the amount of money that is in circulation cannot be separated from the practice of fractional reserve banking, as revealed by Meera and Larbani (2009), Ishaq and Mahjabeen (2015) and Lainà (2015). These findings indicate a historical similarity with al-Maqrizi, when the government printed excess money, which led to inflation. A call for the return to the gold-based monetary system is also proposed. Ahmad and Yaacob (2014) proved that inflation in the time of the gold-based monetary system was lower and more stable than inflation in the time of fiat money. Mundell (1995) points out that world currency is missing in the current international monetary arrangements. He stresses that inflation almost never happened in the time of the gold standard and the Bretton Woods system.

The coefficient value for money supply of $1.66 \mathrm{E}-14$ shows that if there is an increase in money supply of one unit, while the other variables remain constant, this will increase the CPI value by $1.66 \mathrm{E}-14$. Vice versa, if money supply decreases by 1 unit, while other variables are fixed, this will reduce the CPI value by 1.66E14. In other words, inflation could increase by $1.66 \%$ if there is an increase in the amount of money of USD 100 trillion.

Likewise, tax variables have been statistically proven to have a positive effect on the CPI. During al-Maqrizi's time, the main source of tax was land tax. High taxation on the agricultural sector results in general price increases. This result is contrary to the general theory of conventional economics, which states that taxes are needed to reduce inflation by reducing the money supply. Low taxes are expected to stimulate economic growth (Mankiw, 2016); tax cuts could provide incentives for workers to increase aggregate supply (AS) and aggregate demand (AD) by increasing household disposable income.

Based on AD and AS theory, there are two possible reasons why taxes could have a positive effect on inflation: a) taxes affect production costs, thus pushing the AS curve to the left (reduced production), with the decline in production greater than the decrease in consumption due to tax increases; and b) in the midst of economic growth, a more appropriate explanation might be that tax increases make the AS movement slower than the rising AD curve, so that demand is greater than supply, and prices go up (inflation). In general, the positive relationship between tax and CPI shows that tax has more effect on the production aspect (AS) than on demand $(\mathrm{AD})$ 
The coefficient value for the tax variable is 2.39777 , indicating that if there is an increase in the ratio of tax revenue to GDP of 1 unit, while the other variables are constant, this it will increase the CPI value by 2.339777 . Vice versa, if the ratio of tax to GDP decreases by one unit while other variables are constant, this it will reduce the CPI value by 2.339777 .

Different results were obtained for the natural disaster variable. Based on the estimation, it can be seen that the ND variable statistically shows no influence on the CPI value. The absence of any influence could be down to various factors, including: a) the impact of the disaster is only regional, in the area affected by the disaster; b) the increasingly strong globalisation flow, so that market intervention by the government in overcoming disruptions on the supply side could be implemented quickly and well; and c) the ability of governments to cope with disasters, especially those of developed countries. This situation can also be seen in Miles's (2016) study, which revealed that natural disasters only had a positive impact on inflation in developing countries. As for developed countries, natural disasters do not affect the level of inflation.

\section{CONCLUSION AND RECOMMENDATION}

\subsection{Conclusion}

The results of this study prove that Imam al-Maqrizi's thoughts related to the causes of inflation are still relevant today. The human error factor is the main factor which causes inflation. Such factors include high levels of corruption, interest rates and taxes, and the large amount of money in circulation. All these factors are positively correlated to inflation. The natural disaster factor, as stated by al-Maqrizi, is no longer relevant. This is possibly because the impact of natural disasters is often not felt nationally, but only in the surrounding area. In addition, the government's ability to handle natural disasters is improving.

\subsection{Recommendation}

Based on the results, it is recommended that governments reach international agreement to return to the use of gold and silver as a global currency, as suggested by al-Maqrizi. Moreover, governance should be strengthened to prevent corruption.

For researchers, the study could be expanded to comparative analysis between developing and developed countries, and between OIC countries and non-OIC ones. Likewise, more research on other past scholars' thoughts about inflation and economic crisis is also needed.

\section{REFERENCES}

Aisen, A., \& Veiga, F. (2006). Political Stability Influence Inflation. Journal of Money, Credit and Banking, 38(5),

Al-Bukhari. (1419 H). Al-Jami' Al-Musnad Al-Shahih atau Shahih Al-Bukhari. Riyad: Dar Al-Salam.

Al-Haritsi. (2003). Al-Figh Al-Iqtishadi li Amir Al-Mu'minin Umar bin Al-Khaththab. Jeddah: Dar Al-Andalus Al-Khadra'. 
Al-Maqrizi. (2007). Ighatsah Al-Mummah bi Kasyfi Al-Ghummah. Maryiotia: Ein for Human and Social Studies

Al-Marhubi, F. A. (2000). Corruption and Inflation. Economics Letters, 66(2), 199202. https://doi.org/10.1016/S0165-1765(99)00230-X

Al-Thabrani. (1415 H). Al-Mu'jam Al-Ausath. Abu Dhabi: Dar Al-Haramain. Ascarya. (2011). How to Eradicate Inflation under Dual Monetary System: The Case of Indonesia. Paper presented at $8^{\text {th }}$ International Conference on Tawhidi Methodology Applied to Microenterprise Development, Jakarta, Indonesia

Ascarya. (2013). Analysis of Financial Crisis and How to Prevent It in Islamic Perspective using Vector Error Correction Model. Paper presented at 9th International Conference on Islamic Economics and Finance, Istanbul, Turkey.

Ascarya. (2017). The Real Determinants of Financial Crisis and How to Resolve it in Islamic Economics Perspective. International Journal of Economic Research, 14(13)

Barro, R. J. (2009). Rare Disasters, Asset Prices, and Welfare Costs. American Economic Review, 99(1).

Carter, M.R., Little, P. D., Mogues, T., \& Negatu, W. (2007). Poverty Traps and Natural Disasters in Ethiopia and Honduras. World Development, 35(5),

Case, K. E., Fair, R. C., \& Oster, S. M. (2012). Principles of Economics (10 ${ }^{\text {th }}$ ed.). Pearson Prentice Hall. https://doi.org/10.1017/CBO9780511794193

Doepke, M., \& Schneider, M. (2006). Inflation and the Redistribution of Nominal Wealth. Journal of Political Economy, 114(6), 1069-1097. https:/doi. org/10.1086/508379

Heinen, A., Khadan, J., \& Strobl, Eric. (2019). The Price Impact of Extreme Weather in Developing Countries, The Economic Journal, 129(619), 1327-1342, https:// doi.org/10.1111/ecoj.12581

Ibnu Katsir. (1999). Tafsir Al-Qur'an Al-'Azhim. Dar Thayyibah

Ishaq, H. M., \& Mahjabeen. (2015). Impact of Fractional Reserve Banking System on the Ownership Structure of Economy. Pakistan Journal of Social Sciences, 35(2), 619-628.

Kumhof, M., \& Benes, J. (2012). The Chicago Plan Revisited (Working Papers WP 202). IMF. https://doi.org/10.5089/9781475505528.001

Laeven, L., \& Valencia, F. (2013). Systemic Banking Crises Data base. IMF Economic Review, 61(2), 225-270.

Lainà, P. (2015). Money creation under full-reserve banking: a stock-flow consistent model. Cambridge Journal of Economics, 43(5), 1219-1249, https://doi. org/10.1093/cje/bey034

Mankiw, N.G., (2009). Macroeconomics (9th ed.). Worth Publishers.Meera, A., \& Larbani, M. (2009). Ownership effects of fractional reserve banking: an Islamic perspective. Humanomics, 1-25. https://doi.org/10.1108/08288660910964175

Parker, M. (2016). The Impact of Disasters on Inflation (Working Paper Series WP 1982). European Central Bank. https://doi.org/10.1111/j.1467-629X.1980. tb00220.x

Parkin, M. (2012). Macroeconomics (10 ${ }^{\text {th }}$ Ed.). Pearson. Phiri, A. (2018), Nonlinear impact of inflation on economic growth in South Africa: a smooth transition regression analysis. International Journal of Sustainable Economy 10(1):1. https:// doi.org/10.1504/IJSE.2018.10009435 
Rentschler, J. E. (2013). Why Resilience Matters: The Poverty Impacts of Disasters (Policy Research Working Paper WP 6699), World Bank https://openknowledge.worldbank.org/handle/10986/16915.

Samimi, A. J., Abedini, M., \& Abdollahi, M. (2012). Corruption and Inflation Tax in Selected Developing Countries 1, Middle-East Journal of Scientific Research 11 3), 391-395.

Sarel, M. (1996). Nonlinear Effects of Inflation on Economic Growth. IMF Economic Review, 43(1): 199-215. https://doi.org/10.2307/3867357

Zhang, C., Meng, C., Getz, L. (2014). Food Prices and Inflation Dynamics in China. China Agricultural Economic Review. 6 (3), 395-412, https://doi.org/10.1108/ CAER-12-2012-0140 
This page is intentionally left blank 